\title{
TRAS MEDIO SIGLO DE EL HOSTIGANTE VERANO DE LOS DIOSES: FANNY BUITRAGO Y LA “AUTENTICIDAD” CARIBE
}

\author{
POR \\ NADIA CELIS \\ Bowdoin College
}

Quiero acercarme al mundo del político de la calle, de la señora gorda, de la adolescente enamorada, convertirme en niña y en policía. Para mí, ser escritora es ser muchas gentes, de todas las layas, e intentar un imposible fresco de la Colombia actual. Y, claro, trabajar la palabra, jugar con ella, hasta que adquiera color, sabor, ritmo... a historia de donde venga. No me importa que salga del mundo infantil, de la política, de la violencia o de la cursilería. Que venga de donde venga...

Fanny Buitrago

\section{UNA ESCRITORA COSTEÑA}

Al sol de hoy, medio siglo después de la publicación de su primera novela, Fanny Buitrago (Barranquilla, Colombia) ${ }^{1}$ madruga a diario y escribe varias horas. Luego se prepara un desayuno completo y come con un gusto que su figura delgada y ágil no resiente ni delata. Aunque edita en una computadora, desconectada del internet para evadir virus y piratas cibernéticos, aún escribe a mano en cuadernos de colegiala. En ellos dibuja también, barcos y pájaros de colores que ilustran sus relatos infantiles. Así mantiene viva una de sus primeras pasiones artísticas, la de la pintura, la cual le heredó, además, dos de sus grandes amores: Alejandro Obregón, con quien tuvo una relación íntima en su juventud y sostuvo un nexo profundo y definitivo, y Enrique Grau, amigo entrañable cuyo cariño y fascinación por la escritora atestiguan variedad de retratos colgados en las paredes de su apartamento. Uno de esos retratos llama particularmente la atención: una Fanny de cabellos cortos y atuendo masculino se yergue frente al observador, sus ojos desviados hacia la mano izquierda levantada sin esfuerzo a la altura de los hombros, donde un minúsculo hombre desnudo se sostiene en un pie, en difícil acto de equilibrio, sobre el dedo índice de la mujer. Los dedos de la mano derecha

\footnotetext{
Nacida entre 1943 y 1945, la fecha oscila dependiendo de la fuente y la escritora misma prefiere no
} precisarla. 
sensualmente descansando sobre sus labios, acentúan una expresión entre divertida y meditativa, como preguntándose si ha de mover el dedo y dejar al hombre caer. Casi a la altura de su vientre, colgada de una cadena, una mano diminuta empuña un ojo que nos mira mientras la vemos mirar al hombre. "Este es un cuadro de Grau. Él decía que cuando yo quería, no que fuera una constante sino que cuando quería, manejaba a la gente con un dedo. Y que yo tenía un tercer ojo. Puede ser el tercer ojo del escritor, ¿no?”.2

Ese tercer ojo, curioso, precoz, inquisitivo y certero, marcó desde muy temprano el destino de Fanny Buitrago. Letty Buitrago, hermana, editora y agente de la autora, recuerda como "desde muy pequeña, Fanny miraba a la gente en silencio, con ojos curiosos, estudiando su manera de proceder y se creía que a veces juzgando y censurando sus actos, pero en realidad era con ojo observador". A los cinco años, un accidente que le robó parte de la visión, agudizó irónicamente el ojo de la escritora al retraerla y volcarla por completo hacia la lectura. Criada en Soledad, un pueblo del Caribe colombiano al pie de Barranquilla, en la casa de los abuelos maternos, entre libros, tías que contaban cuentos y rodadas al cine con el abuelo Tomás, Fanny Buitrago se estrenó pronto en el oficio, contando historias a sus hermanos y primos, que intercambiaba por monedas o tareas domésticas. "La aventura diaria quedaba inconclusa para reanudarla al día siguiente a capricho de la relatora... Todos los niños hacíamos lo que nos pedía con tal de seguir oyendo lo que le había ocurrido a Juanito desde la última vez que ella nos había embrujado con sus peripecias estupendas"-cuenta Letty. De aquellas historias viene su serie de relatos juveniles: La casa del abuelo (Premio de la UNESCO en 1979), La casa del arcoíris (1986), Cartas del palomar (1988) y La casa del verde doncel (1990), que empezó a escribir para complacer a los nuevos niños de su familia: sus sobrinos. Cuando la pequeña Fanny entró al colegio, ya había leído más que algunas de sus profesoras. A los 9 años escribía cuentos y obras de teatro, algunas representadas en el teatro del colegio. Mas su informada curiosidad la llevaría pronto, dice Letty, "de ser la mejor de su clase a convertirse en una alumna incómoda". Por todo esto, quizás, la autora recuerda su niñez sin nostalgia, reinventándo en la ficción "a la niña despreocupada que no fui... Yo fui una niña pensante y los niños pensantes sufren. Yo disfruto más la vida hoy que cuando era niña".

Ya en su adolescencia, el trabajo de su padre, que viajaba para instalar oficinas para una compañía extranjera, llevó a la familia a establecerse sucesivamente en Medellín, Ibagué, Manizales, Bogotá y Cali. En los periódicos de esta última ciudad, El País y El Occidente, Fanny Buitrago publicó sus primeros artículos y cuentos. De aquel vaivén juvenil le quedó también la tendencia al nomadismo que la llevaría a vivir y escribir desde escenarios tan variados como San Andrés, Iowa, Estocolmo, Madrid, Berlín, Cartagena y Bogotá, donde reside actualmente.

2 Las declaraciones en adelante citadas provienen de entrevistas personales realizadas en 2007, 2008 y 2011, así como de mi correspondecia con Letty Buitrago en el transcurso de los mismos años.

$111 \frac{\text { Revista Iberoamericana, Vol. LXXXII, Núms. 255-256, Abril-Septiembre 2016, 471-486 }}{\text { ISSN 0034-9631 (Impreso) }}$ 
En diciembre de 1962, el Magazín Dominical de El Espectador adelantó un fragmento de la que sería su primera novela, El hostigante verano de los dioses. Fanny Buitrago había publicado para entonces varios cuentos en el Magazín y el suplemento literario de El Tiempo ${ }^{3}$ dando lugar al primero de una larga e incesante serie de episodios insólitos con sus lectores, que se resistieron a creer en la existencia de la escritora hasta ver una fotografía. Aquella muchachita delgada y de largas trenzas daría mucho más de qué hablar al año siguiente cuando Tercer Mundo publicara su novela. Buitrago exhibía a sus 19 años una escritura madura, reveladora no sólo de su talento innato, sino de la precoz sabiduría de una lectora insaciable que había devorado con provecho las pobladas bibliotecas de su padre y su abuelo materno.

Complejo relato sobre un grupo de intelectuales de una ciudad del trópico lanzados a la fama por un libro anónimo que sacude la escena literaria nacional, El hostigante verano de los dioses es una novela autoconsciente, con riesgos experimentales y logros estilísticos comparables a los de los más audaces escritores de la "nueva novela" y el Boom latinoamericano. La novela es también la piedra angular de la trayectoria literaria de Fanny Buitrago, sin duda la primera escritora de oficio del Caribe colombiano, quien, a lo largo de medio siglo, ha reiterado su vocación relatora a través de piezas teatrales, colecciones de cuentos, volúmenes de literatura infantil y siete novelas, entre las cuales las dosúltimas, Señora de la miel (1996) y Bello animal (2002), cuentan con traducciones al italiano, el alemán, el holandés, el francés y el inglés. ${ }^{4}$ No obstante, la obra de Fanny Buitrago carece aún de un estudio completo que dé cuenta de su aporte a la literatura nacional y la sitúe en el contexto pancaribeño y latinoamericano. ${ }^{5}$ Revisando algunos de los escollos en la recepción de su obra que han dificultado el reconocimiento y la presencia de Fanny Buitrago en el canon nacional, este ensayo propone una lectura de las contradicciones suscitadas por su figura a la luz de una mirada caribeña. En diálogo

3 Por ejemplo "Un helado de moras para Juanita Campana", "Hoy es mi cumpleaños", "Un cielo blanco, de nubes blancas" y "El niño, el búho y la lluvia".

4 Buitrago ha publicado a la fecha, una obra de teatro, El hombre de paja, ganadora del Premio nacional de teatro en 1964, en un volumen compartido con su primera colección de cuentos Las distancias doradas; los volúmenes de relatos La otra gente (1974, elegido por la Revista Semana en 1999 como uno de los mejores libros colombianos del siglo XX), Bahía sonora (1975), ;Libranos de todo mal! (1989) y Canciones profanas (2009). Entre las novelas están: El hostigante verano de los dioses (1963), Cola de zorro (1970), Los pañamanes (1979), Los amores de Afrodita (1983), Los fusilados de ayer (1987), Señora de la Miel (1993) y Bello animal (2002). Sus obras para niños y jóvenes incluyen La casa del abuelo (1979, premio de la UNESCO de Literatura infantil), La casa del arco iris (1986), Cartas del palomar (1988) y La casa del verde doncel (1990) e Historias de la rosa luna (2008). Las traducciones de sus obras incluyen Señora Honeycomb (1996), La signora del miele (1999).

5 Entre las excepciones cabe destacar el estupendo trabajo monográfico de Elizabeth Montes Garcés, $E l$ cuestionamiento de los mecanismos de representación en la novelística de Fanny Buitrago (1997) si bien cubre solo hasta la publicación de Señora de la miel. 
con la crítica previa y con reflexiones de la autora, compartidas en sucesivas entrevistas personales, intento bosquejar una bitácora para ese estudio posible y necesario.

Recibida, en principio, con entusiasmo en el medio intelectual capitalino y nacional, ${ }^{6}$ las contradicciones en torno a la figura y la obra de Fanny Buitrago no se hicieron esperar $\mathrm{y}$, en consecuencia, el aporte de su primera novela a la historia de la literatura colombiana terminaría minimizado. Este fenómeno podría atribuirse, en primera instancia, a la temeraria vinculación, por parte de la crítica literaria periodística, de Fanny Buitrago con la fugaz y pronto institucionalizada irreverencia del grupo de los Nadaístas, pese a la insistente negativa al respecto por parte de la autora. Ésta, entre otras incomprensiones ligadas a su constante migración geográfica, estilística y temática, retrasarían además el posicionamiento de la obra de Fanny Buitrago en la tradición narrativa del Caribe colombiano, entre cuyos críticos su pertenencia a esta tradición sigue siendo objeto de omisiones y controversia. ${ }^{?}$

La efervescencia intelectual del Caribe colombiano desde los años 20 es considerada hoy, tras la atención generada por Gabriel García Márquez hacia sus compañeros de formación, el caldo de cultivo de la modernización de la literatura colombiana. Si bien en la década de los 50, época de la irrupción del legendario "Grupo de Barranquilla", Buitrago era una niña, años después sería cálidamente acogida por dos de sus miembros más notables, Obregón y Grau. Fanny comparte con los escritores "costeños” esa tendencia a la transgresión, cuyo motor identificó uno de los más acuciosos críticos de la literatura del Caribe colombiano, Jacques Gilard, como la "casi rabiosa defensa de la libertad del cuerpo y la conciencia, ese continuo llamado para que cada quien se asuma como lo que es" (3). Gilard atribuye esta actitud a la pugna ancestral entre los valores populares surgidos del mestizaje y las relaciones de producción impuestas por la colonización y su adepta moralidad judeocristiana.

Por su parte, Seymour Menton remite la fecundidad de la Costa Caribe colombiana en la primera mitad del Siglo XX al vertiginoso crecimiento del puerto y la consecuente

6 Entre los más entusiastas de sus seguidores estuvieron los directores de suplementos literarios, Gonzalo González, GOG, del Magazín Dominical de El Espectador, y Eduardo Mendoza Varela, de las Lecturas Dominicales de El Tiempo, con quienes sostuvo una sólida amistad. En la década que transcurrió entre sus primeras dos novelas, los cuentos de Fanny Buitrago continuaron siendo regularmente publicados en estos suplementos, al igual que en revistas colombianas como Letras Nacionales, e internacionales, como Américas. En 1964 Buitrago ganó el Premio Nacional de Teatro con El hombre de paja y en 1968 fue finalista al Premio Seix Barral con Cola de Zorro. En estos primeros años fue además incluida en antologías narrativas y textos críticos como Nuevos narradores colombianos (1968) y La generación del bloqueo y el estado de sitio (1973).

7 Entre los esfuerzos recientes por leer a Buitrago en el contexto de la literatura del Caribe colombiano, cuya importante producción crítica en las últimas décadas había prestado escasa atención a esta autora, cabe destacar el número monográfico de Cuadernos de Literatura del Caribe e Hispanoamericana, La obra de Fanny Buitrago. Crítica, con artículos de quince investigadores (véase, Ortega et al.). 
modernización de la ciudad de Barranquilla, así como a la permeabilidad a las influencias extranjeras que permitiría a los intelectuales costeños, por un lado, recibir, leer con entusiasmo y digerir las influencias de los escritores ingleses y estadounidenses y, por el otro, desarrollar una "conciencia caribeña" con la que desafiarían el tradicionalismo y la dominación cultural capitalina. Fanny Buitrago es la única mujer y la segunda más joven de los diez novelistas nacidos entre 1920 y 1945 que, según este crítico, "complementan la visión macondina de esa otra Colombia anteriormente desconocida en la novelística nacional" ("Especulaciones" 629). Menton destaca novelas como Respirando el verano (1962) de Héctor Rojas Herazo, directo antecedente de Cien años de soledad, La casa grande (1962) de Álvaro Cepeda Samudio, primera en recrear la masacre de los obreros de las Bananeras inmortalizada por García Márquez, y El hostigante verano de los dioses (1963), que "merece especial atención porque se publicó cuatro años antes de Cien años de soledad y porque contiene una presentación sutil de la vida trágica de los peones bananeros contrastada con la de los protagonistas seudointelectuales, en un ambiente tropical basado tanto en Cali como en Barranquilla" (Caminata 478). En efecto, Fanny Buitrago concluyó la novela en "La Zona" durante una de sus estadías en Guacamayal, Magdalena, en casa de su tía Mercedes González de De la Hoz, propietaria de un almacén que surtía a los trabajadores de la Frutera de Sevilla, cuya salida de la región por presiones sindicales relata al final de El hostigante.

Localizadas en pueblos y ciudades caribeñas, las primeras novelas y relatos de Buitrago, comparten con la obra de los autores regionales rasgos distintivos como la prevalencia de la oralidad y la tendencia a la carnavalización, su desacato sistemático a las convenciones sociales y textuales, además de algunos de los motivos de ese Caribe "mágico" inmortalizado por el Premio Nobel colombiano, entre ellos, la amenaza permanente del deseo en familias endogámicas condenadas a la desolación y el fatalismo colectivo de pueblos atravesados por una violencia endémica. La pertenencia a ese universo común caribeño y las coincidencias con Cien años de soledad han constituido, paradójicamente, un segundo factor en contra de la consideración crítica de El hostigante, al igual que de otras obras previas a la novela cumbre de García Márquez, cuya singularidad se ha sostenido parcialmente sobre el desconocimiento de trabajos anteriores y trayectorias paralelas. Ala sombra de Cien años de soledad atribuye también Raymond Williams en Una década de novela colombiana: La experiencia de los setenta, la escasa atención de los críticos a la "joya literaria” que sería su segunda novela, Cola de zorro, finalista del premio Seix Barral en 1968, el cual, según le informarían posteriormente a la autora, no le fue otorgado debido a las reticencias de algunas figuras de la academia colombiana a las que el jurado internacional llamó para indagar en la procedencia de la "desconocida" escritora.

Desde su primera novela, escribiría Buitrago dos décadas más tarde, aprendió una lección: "Mucha gente rechaza ciertos libros a priori, pues ofenden sus principios o los enfrentan a situaciones que consideran imposibles" ("El oficio no oficio" 5).

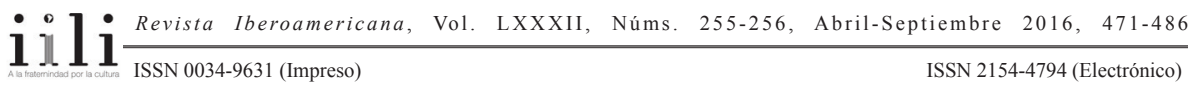


Que el ambiente literario colombiano no estaba listo para su desafío, es obvio en la displicencia encontrada por García Márquez mismo en sus primeros años hacia los escritores del Caribe por parte de la crítica capitalina. Mucho menos preparada estaba la academia nacional para que una muchacha de 19 años expusiera y se burlara de las tradiciones de una sociedad profundamente católica, de los prejuicios y jerarquías raciales heredados de la Colonia, de los vicios y la mezquindad de sus élites y del arribismo burgués. Y muchísimo menos para que, además, pusiera en tela de juicio el alcance de la irreverencia practicada por los escritores e intelectuales de la época. ${ }^{8}$ Pues si bien El hostigante contiene una crítica amplia a los valores sociales, su sátira se dirige, en última instancia, a la "pose" y las pretensiones "revolucionarias" de los intelectuales mismos. Aunque con alusiones evidentes al "Manifiesto Nadaísta" (1957), el blanco de su parodia puede buscarse entre los bohemios reunidos en el Café Bastilla de Medellín, los de El Cisne de Bogotá o, como sugiere Jorge Ordóñez, en los del Café de los Turcos en Cali o los de La Cueva, tertuliadero del "Grupo de Barranquilla" (25). Dibujándolos como brillantes pensadores y valientes iconoclastas, pero a su vez como narcisistas, contemplativos y pasivos, elitistas y hasta racistas, prestos a enmascarar con su duda existencial su conformidad o su arribismo, el retrato de "los dioses" esbozado por El hostigante cuestiona, entre otras de las premisas de esa revolución intelectual, el lugar asignado a las mujeres, tratadas como apéndices u objetos de intercambio para la complacencia de los genios. Desde las orillas del panteón, son sus visiones, en las voces de cinco narradoras superpuestas, las encargadas de desnudar a cada personaje y revelar su "pose". Si bien los escritores costeños habían preparado el terreno para arrancarle las vestiduras al poder, lo que no se había hecho desde el Caribe ni en la literatura colombiana, lo que vendría a hacer ese tercer ojo prematuramente entrenado de la escritora, era exponer la condición patriarcal de ese poder y las contradicciones de los escritores mismos ante ese punto ciego. " Es que esa es la historia del país... todavía

8 Las palabras de uno de sus primeros reseñistas, Agustín Rodríguez Garavito, atestiguan la sospecha, maquillada de paternalismo, que despertó la novela: "Novela esta que retrata amoralidades, excesos, frustramientos. Lectura nociva para quienes crean aún en la belleza de muchas cosas y las defiendan con hermoso coraje. Pero rica en valores novelísticos y de una técnica muy bien lograda en una muchacha de 18 años como Fanny Buitrago" (839). No faltó tampoco quien acudiera a estrategias menos sutiles de descalificación, aludiendo, por ejemplo, a la falta de educación formal de Buitrago -que en cualquier escritor habría sido signo inequívoco de su genio- como "escasa evolución intelectual" (Peña Gutiérrez 182).

9 En diferentes grados del espectro en cuanto al cuestionamiento del poder patriarcal en los escritores del Caribe colombiano habría que colocar, por ejemplo, a La casa grande de Álvaro Cepeda Samudio y Respirando el verano de Héctor Rojas Herazo, en cuya caracterización puede rastrearse una comprensión, compasión y disgusto hacia la subordinación de la mujer, por el contrario idealizada en la figura de la matriarca en Cien años de soledad. El extremo feminista del espectro se dará dos décadas más tarde, con la colección de cuentos, Algo tan feo en la vida de una señora bien (1980) y la novela En diciembre llegaban las brisas (1987) de Marvel Moreno (1949-1994), la otra gran narradora del Caribe colombiano. 
la mayoría de las mujeres no existen a menos que estén en relación con el elemento masculino. Y yo al escribir esa novela no lo tenía tan claro, pero mi cerebro lo sabía".

Sin embargo, el eje de las obras de Buitrago no está en la crítica al patriarcado y su proyecto ético y estético tampoco privilegia una agenda feminista. ${ }^{10} \mathrm{La}$ autora ha defendido, además, a capa y espada, su derecho a ser "escritor" más allá de las reivindicaciones o las agrupaciones promovidas por la crítica feminista, ${ }^{11}$ aunque sin desconocer las dificultades de ser una escritora en Colombia. ${ }^{12}$ El proyecto desacralizador de Buitrago apunta a la condición artificial del sujeto en un orden jerárquico basado a su vez en la apariencia, la procedencia, las ideologías y los estilos de vida. Medio siglo después, Buitrago continúa expresando la preocupación por lo que ha sido desde $E l$ hostigante un eje central en su obra: "La gente no tiene derecho a ser quien es"-denuncia. He allí el origen de "la muerte de la libertad real, interior, personal," sacrificada en pro de "un ejército de gente que compra y mata". Desde esa primera novela, Buitrago llevaría al paroxismo ese tan caribeño clamor por la autenticidad que habían iniciado sus predecesores.

\section{UNA NOVELA POSMODERNA}

El hostigante verano de los dioses pone en evidencia otro motivo recurrente a todo lo largo de la obra de Buitrago: su preocupación por la relación entre texto y sujeto, es decir, por el papel de la literatura como guión del artificio, como discurso forjador de imaginarios y fantasías colectivas y como herramienta de formación individual. $\mathrm{Su}$ constante experimentación con el lenguaje, los procedimientos narrativos y los límites de los géneros, apunta también a una concepción del lector, continuamente convocado a la manufactura del sentido por las "trampas" metaficticias y las estructuras deliberadamente abiertas de sus obras. De allí que El hostigante haya sido considerada la

\footnotetext{
${ }_{10}$ Alejandro Martínez comenta a este respecto como, si bien la experiencia de ser mujer en un mundo que la obliga a "defenderse como gato boca arriba" es crucial para entender su mundo "sembrado de lágrimas, sueños, encantamientos, pescadores, mentirosos y amantes furtivos al lado de intelectuales impíos y mujerzuelas que no reconocen su oficio", Buitrago no define sus personajes femeninos "con compasión ni las defiende del acoso de los hombres: deja que ellas mismas materialicen sus elementos que las identifican, deja que hablen libremente, deja que los demás las escuchen y entonces sí, surge el conflicto". Esta representación de las mujeres ha dado lugar a interpretaciones diversas y constituye un aspecto polémico para la crítica, en particular para la crítica feminista.

11 Ver, por ejemplo, su ensayo: "El verso aquel, el sexo aquel" en la revista Quimera.

12 En una entrevista con Raymond L. Williams, Buitrago comenta, por ejemplo, las reacciones violentas a su obra y a su persona, así como las expectativas inusitadas hacia las escritoras, de quienes se espera sean bibliotecas ambulantes, además de la incapacidad de distinguir lo real de lo imaginario por parte de críticos y lectores que demandan, airados y superiores, explicaciones a todo lo que escribe ("An Interview" 160-61).
} 
primera obra posmoderna en Colombia y, a su vez, un enlace entre la actitud moderna y la posmodernidad. Como señala Elizabeth Montes Garcés, la de Buitrago es "una narrativa sin ánimos totalizantes, que plantea los riesgos del proceso de escritura" y trasluce su desconfianza tanto hacia lo nuevo u original -motor de la exploración moderna-como hacia toda autoridad, incluida la textual (El cuestionamiento 8-15). La obra en pleno de Fanny Buitrago resume además esa fascinación posmoderna hacia el simulacro del sujeto y del mundo: "El mundo es un teatro y en este mundo cada quien tiene su pose, su máscara", afirma la autora.

Valiéndose de las voces, espacios y tipologías provistas por el gran montaje de la sociedad misma, Buitrago localiza sus personajes e historias en escenarios y situaciones familiares para los lectores, desde pueblos remotos hasta grandes urbes y, más recientemente, en los espacios de interacción promovidos por los medios masivos y la tecnología virtual. Por sus casas, calles y pantallas desfilan, en palabras de Luz Mery Giraldo, "figuras deleznables, atractivas, complicadas, descomplicadas, sofisticadas, elementales, inteligentes, pobres de espíritu, feas, bonitas, etc., [que] son efectos miméticos tanto de la vida como de la literatura, al igual que los habitantes de las ciudades y las provincias, los burgueses y los aristócratas de apellido, de clase o de dinero" (207). A ese "engañoso apego a la realidad" atribuye Giraldo la dificultad para escribir sobre Buitrago.

En efecto, el hermetismo de su obra a los esquemas interpretativos convencionales es evidente en los análisis existentes sobre Buitrago, los cuales a menudo se quedan en disquisiciones formales. Su recurrencia al humor y la parodia ha llevado a calificar sus obras como satíricas, si bien su caricaturización indiferenciada de las tipologías culturales y las instituciones sociales no siempre deja claro el "mensaje" ni el objeto de su crítica. Dos de sus libros catalogados alternativamente como colecciones de cuentos y como novelas, en realidad, atentan contra la estabilidad de ambos géneros. La variedad de sus temáticas, oscilante entre asuntos considerados "serios" como la violencia política y temas "triviales" como la publicidad, las realidades virtuales y la industria de la belleza, en las últimas novelas, también ha despertado reticencias. Igualmente problemático ha sido su explícito rechazo a todo intento por asociarla con movimientos literarios, sociales y políticos y su escaso interés en participar en eventos para escritores. Patricia Aristizábal señala además la controversia suscitada por la negativa de la autora a intervenir en congresos y a figurar en antologías dedicados exclusivamente a escritoras (53). Su resistencia activa al encasillamiento no deja de ser un gesto costoso en el actual mercado del libro, en el que la edificación y la comercialización de la figura del autor se han vuelto un imperativo.

La lectura total de la obra de Fanny Buitrago evidencia cómo la resistencia a asumir banderas ideológicas es no sólo una posición personal, sino una estrategia primordial para el programa literario de la autora. Su condición liminal y esa perenne desconfianza hacia

$111 \frac{\text { Revista Iberoamericana, Vol. LXXXII, Núms. 255-256, Abril-Septiembre 2016, } 471-486}{\text { ISSN 0034-9631 (Impreso) }}$ 
toda autoridad y postura, informada por su "tercer ojo", han hecho de Fanny Buitrago una testigo rigurosa de sus tiempos, si bien la han colocado en una situación delicada ante las expectativas y el ánimo clasificatorio de lectores y críticos. Su "engañoso" mimetismo es, además, un mecanismo fundamental de su escritura, avocada a revelar la ficción implícita en la realidad misma. La trampa de su imitación de lo real se delata a través de variedad de guiños al lector, en una permanente desestabilización de la representación textual y sus mecanismos que, como señala Elizabeth Montes Garcés, expone y mina su propia autoridad, haciendo de la narrativa el medio para "cuestionar tanto los límites de la capacidad representativa de la novela como género, como la ideología que sustenta la cultura y el sistema social" ("El cuestionamiento" 324). Al servicio de este propósito, se ponen técnicas como el collage, las puestas en abismo tanto con lectores, autores y novelas, dentro de las novelas, como con fotografías y universos virtuales, al igual que la superposición de las voces y de los niveles narrativos. Montes Garcés destaca, además, la transtextualidad paródica, que le permite enfrentar al lector a las complicidades entre la estructura social y "los valores reforzados por la literatura culta, por la literatura popular y por los medios masivos de comunicación [que] han contribuido a establecer una serie de patrones sexuales y sociales encasillantes e insulsos tanto para la mujer como para el hombre" (El cuestionamiento 19). Laura Trujillo ilustra también la ambivalencia de sus paratextos (advertencias, prólogos, epílogos), los cuales, en lugar de asumir su papel tradicional de legitimación de la autoridad del escritor, se transforman en sus obras en "un comentario crítico sobre fenómenos como la arbitrariedad de las clasificaciones genéricas, la fragilidad de los límites entre las formas y los géneros artísticos, y entre realidad y ficción" (94).

Con estos gestos, Buitrago advierte constantemente al lector acerca de la condición artificial de la ficción y sus efectos en individuos reales y, por extensión, sobre la condición artificial de la realidad. Así, su mimetismo se revierte contra las definiciones, convenciones e instituciones que regulan los impulsos individuales y las relaciones, el deseo y los sentimientos, cuyas forzadas "poses" la autora aprovecha para convertir a sus personajes en caricaturas de sí mismos. Los códigos morales y la reputación, el matrimonio y la familia, las tradiciones religiosas y los nuevos cultos de la "sociedad del espectáculo", los partidos políticos, los gremios y las asociaciones intelectuales, el Estado y la Nación, son todos blanco de una elaboración grotesca de lo real que, desde una simulación posmoderna, produce, sin embargo, no sólo una crítica aguda de las fabulaciones culturales y sus efectos deshumanizantes sobre hombres y mujeres, sino, a su vez, un comentario sobre lo real y sobre el rol del escritor como artífice de esas realidades. Este último impulso de Buitrago, según comenta Victoria Borsó, supone un excepcional llamado a "una ética de la responsabilidad intelectual en el manejo de la imaginación" (92). Cuestionar la literatura como artefacto ideológico y cultural es, en Buitrago, parte de un cuestionamiento mayor de los efectos de la farsa, en un gesto que

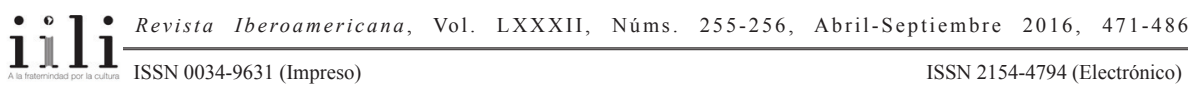


la distancia de la celebración acrítica del simulacro social y la disolución de la identidad que caracteriza la posmodernidad ortodoxa.

En el origen de esa suerte de escogida liminalidad que caracteriza su perspectiva, Buitrago sitúa la coexistencia de la modernidad y de la posmodernidad en la realidad colombiana: "Somos un país que pasó de la mula al avión, pero seguimos en la mula... donde se aceptan los cambios tecnológicos pero se previenen los mentales... Y tanta tecnología adormece a la gente." Se trata también de un país donde, a fuerza de coexistir con los monstruos -secuestrados, desaparecidos, políticos y modelos- "se vive entre la realidad y la irrealidad, en una atmósfera que va y viene entre la risa y el miedo". $\mathrm{Al}$ atentado contra la visión de sí y del mundo que la realidad misma supone, Buitrago aúna la "guerra contra el pensamiento" operada por el poder que controla los medios y la tecnología:

Cada época tiene una guerra en contra de tópicos. En una época fue una guerra contra Dios, contra la idea de Dios... nosotros estamos en una época en que la guerra es contra el pensamiento. La idea es que la gente no piense. Que haga deporte, que vaya a espectáculos...

Yo de niña vi teatro y no sé si era bueno o malo pero era maravilloso, uno veía teatro [en la televisión]. Ahora es la telenovela por la mañana, al medio día y por la noche. El crimen por la mañana, al medio día y por la noche... Ya los libros no son para leerlos, sino para consumirlos, como el cine... Ya no se montan las grandes obras de la literatura universal sino espectáculos que da lo mismo ver Sábados Felices... Estamos creando, ya no consumidores sino esclavos. Se educan las clases que van a gobernar y el resto que consuma y no piense. La guerra es contra el pensamiento... el libro que se promociona es el que no hace pensar... [Por eso] Mempo Giardinelli dice que "los que publican libros son miles, pero los escritores son pocos".

Ni siquiera su condición de escritora se salva del escrutinio del "tercer ojo" de Buitrago. "No me siento escritora" dice, trasluciendo en la apreciación de su oficio y de sí misma una desconfianza hacia el artificio similar a la de sus textos. De los congresos, homenajes y eventos dice que quitan tiempo para escribir y le niegan el valioso privilegio, tan necesario para una autora, de camuflarse: "la única manera de observar es el anonimato". Y aunque reconoce la necesidad ocasional de la "pose" ("cuando me toca ser escritora lo soy en serio. Me convierto, como los actores"), Buitrago sigue defendiendo, tanto en su carrera como en su literatura, el derecho de ser más allá de "la que escribe":

la vida es otra cosa... no se puede ser escritora sino cuando se escribe o cuando te entrevistan. Del resto... hay que hacer el desayuno, hacer el mercado... ir a la lavandería, que las sábanas, que hay que coser. Porque cuando yo de pronto tengo una evasión y soy escritora en momentos en que no debo, entonces se quema la sopa... y hasta alguna

$111 \frac{\text { Revista Iberoamericana, Vol. LXXXII, Núms. 255-256, Abril-Septiembre 2016, } 471-486}{\text { ISSN 0034-9631 (Impreso) }}$ 
vez llegué a la oficina hace un tiempo cuando trabajaba en publicidad con un zapato de un color y otro de otro porque estaba pensando en un cuento. Hay que ponerle atención a la vida, o se llega a la oficina con un zapato negro y otro azul.

\section{UNA MIRADA CARIBEÑA}

En La isla que se repite. El Caribe y la condición posmoderna (1981), uno de los más famosos tratados sobre la caribeñidad, el crítico cubano Antonio Benítez Rojo dedica un capítulo a la tercera novela de Fanny Buitrago, Los pañamanes, sugerentemente titulado "La memoria de la piel". Los pañamanes registra, desde el punto de vista de un grupo de sus comunidades negras: los tinieblos, la historia y los conflictos "de la piel" que resultan de la sucesiva colonización de las islas de San Gregorio y Fortuna -San Andrés y Providencia- por británicos, españoles y colombianos, los dos últimos catalogados como forasteros o "pañamane...". Benítez-Rojo sitúa esta novela "dentro de la más reiterada tradición literaria del Caribe: la novela-mito, pero no mito épico, sino mito del desarraigado que sueña con reunir los pedazos de su dispersa identidad más allá de las barreras" (231). Como muchas otras novelas "de la Plantación", la de Buitrago, señala el crítico: "es un performance doble; una representación que contiene otra representación. La primera, o mejor, la más visible, está dirigida a seducir al lector de Occidente; la segunda es un monólogo que se vuelve hacia el Yo, hacia el Ser caribeño, intentando mitificar, a la vez trascender simbólicamente su génesis contra-natural"'(232).

Benítez Rojo registra así el doble movimiento, hacia fuera, como representación del artificio para el otro, y hacia adentro, como búsqueda de sí mismo más allá del artificio, implícito en la doble representación y develación que efectúa la escritura de Buitrago, al desnudar tanto a la realidad como a la representación literaria de la misma. Ese segundo movimiento hacia el Ser es atribuido por Benítez Rojo a la necesidad del caribeño de asumir su Otredad y marginalidad ante Occidente, una Otredad "derivada de la violencia de la conquista, la colonización, la esclavitud, la piratería, la guerra lucrativa, la ocupación, la dependencia, la humillación, la miseria, la prostitución e incluso el turismo" (232). Si bien esta Otredad no es exclusiva del caribeño, la exacerbación en el Caribe de la violencia en el choque de los elementos que dieron lugar al Sujeto colonial y postcolonial plantea la paradójica oportunidad de reconocer el artificio. En su tratado sobre el "travestismo" de la identidad caribeña, la escritora puertorriqueña Mayra Santos Febres, dice al respecto que

en el mundo de las categorías fijas, de las identidades demarcadas, de historias de liberación y fundación de estados nacionales, los caribeños nos sabemos raros. Nos proclamamos herederos de culturas que no nos pertenecen, negamos identidades que nunca llegamos a conocer, nos sentimos ciudadanos y nativos de países en los que nunca hemos vivido. Este es nuestro "defecto". (132) 
La poética de Buitrago se distingue no solo por la doble representación y esa conciencia implícita de la condición artificial del sujeto y la identidad, ese uso deliberado de la máscara que Santos Febres denomina "travestismo", sino por la invitación al lector, su "seducción" según Benítez Rojo, a quien se empuja sutilmente a la sospecha y el descubrimiento de la condición "engañosa" de la literatura, la cultura, la historia, lo real. Es este último movimiento el que hace posible la paradójica coexistencia en Buitrago de la condición performativa del texto, que enmasacara y desenmascara a la vez, con un llamado a la autenticidad, desde una nostalgia por la identidad, no ya en sus acepciones modernas de estabilidad y completud, pero aún desde una búsqueda de su expresión "genuina".

He allí, creo, lo distintivo de la "mirada caribeña", entrenada en la coexistencia de lo múltiple y la acumulación de lo imposible que exhiben la piel, su color y cicatrices, para reconocer y revelar el pastiche de la identidad y sus defectuosas suturas. Las y los caribeños son testigos privilegiados y testimonio vivo de la condición cultural de las raíces, de la violencia de la historia y del peso enorme de no ser lo que se es, de no poder serlo y, sin embargo, de desear ser, simplemente ser, más allá del gran mito del "Sujeto" occidental. De allí que la función de la ficción en el Caribe, insiste Benítez Rojo, sea tanto la cancelación de los mitos vigentes como la fundación de un nuevo mito, ya no el de los orígenes, sino uno proyectado hacia el futuro, hacia

un tiempo utópico donde el conflicto de la piel no actúe; esto es, donde la piel pierda su memoria y borre las cicatrices de los latigazos y hierros al rojo, de los cepos y grilletes de la plantación o bien, lave sus propias manchas de culpa, la culpa de las factorías de negros, del terrible middle passage, de la compra-venta de la carne, del mayoral y el barracón. (231)

Hace unos años, tras leer una ponencia sobre las ciudades reales y ficticias de Fanny Buitrago en un Seminario Internacional de Estudios del Caribe, un colega me preguntó cómo podía ser "caribeña" esta escritora nómada, dónde situar la caribeñidad de Buitrago. Daba voz así a otra de las dificultades para clasificar, leer y contextualizar a esta autora. Ante la pregunta, algunos de los oyentes señalaron la omnipresencia del humor grotesco y la actitud carnavalizadora del mundo. Puede alegarse también que su escritura posee esa capacidad de digerir historias, imágenes y conceptos de los contextos y orígenes más variados, para generar un producto textual o cultural único y de resonancia tanto local como universal. Es la capacidad de nuestros más famosos escritores, artistas, músicos.

La caribeñidad de Fanny Buitrago está, además, en una manera de mirar, en esa insidiosa e inquisitiva curiosidad que la mueve a desnudar a todo tipo de seres humanos en el papel y en esa capacidad de vernos en nuestra humanidad sin juzgarnos, sin prejuicio ni moralismo contra el individuo mismo, aunque no por ello sin criticar el montaje

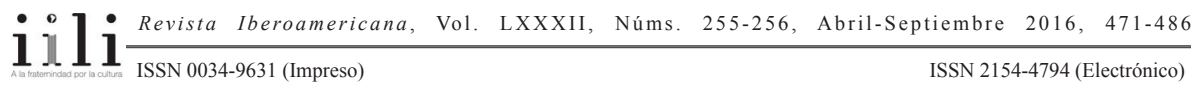


colectivo. Es esa la mirada caribeña: sembrada en la sospecha, lúcida ante las máscaras y hasta celebratoria del juego autoconciente con las mismas, pero aún en busca de la condición última de lo humano. Fanny Buitrago ha llevado esa mirada, texto a texto, más allá de las fronteras regionales.

Con esa visión, Buitrago ha retratado a Colombia, sintetizada magistralemente en esa "ciudad maravillosa e insoportable" que es Bogotá, una urbe en alerta permanente, que "te puede comer", aunque "fascinante como pocas en el mundo... llena de sorpresas de todo tipo... y en donde todo mundo tiene cabida". El sine qua non de la violencia en novelas como Cola de zorro (1970) o Líbranos de todo mal (1989); el aleph de los más inusitados contrastes -entre el amor y la guerra, o entre la degradación y la industria de la belleza- en novelas como Los amores de Afrodita (1987) y Bello animal (2002). Estas dos últimas concentran un giro estilístico que supuso además el paso de la literatura a la cultura de masas - desde el folletín hasta las revistas femeninas y los medios virtuales, como intertexto y blanco de sus pesquisas. Sus novelas más recientes registran también un giro temático, que la autora explica en su cansancio con la representación de la muerte y la violencia en los medios y en la literatura nacional:

Es una promesa que yo me hice, porque aunque el tema de la violencia no lo puedo soslayar, voy a evitar que la violencia sea el centro de mi trabajo... No hay nada más terrible y fascinante que la muerte... y no hay derecho, además de que estamos inmersos en un mundo lleno de violencia a insistir en ella. Estamos abusando del tema de la violencia y hemos dejado de hacernos las preguntas más simples. Desperdiciamos otros temas... el sufrimiento, el consumismo, la belleza... y la fealdad.

El amor, a cuya develación dedica la serie de relatos encadenados que constituye Los amores de Afrodita, es otro de esos temas, al que regresa siempre con particular fascinación por sus trampas y falsas promesas: "El amor no existe. Es un invento del ser humano para poder soportar todo lo demás. Pero es un invento maravilloso" -dice. Sin embargo, la búsqueda del amor genuino, más allá de su institucionalización por el matrimonio o la familia, persiste en sus novelas más recientes. En Bello animal (2002), surgida de la experiencia de la autora como creativa en agencias de publicidad, el amor termina sacando de su "pose" a Gema, la supermodelo, símbolo de una nación enajenada por la obsesión con la imagen y la apariencia en avenencia con la corrupción y la violencia. Colombia, dice Buitrago al explicar la génesis de esta novela, se ha convertido en "una tierra de modelos y de presentadoras de televisión, que van pasando... una cantidad de gente de consumo, a la que consumen como tomar gaseosa o cerveza, y que pasa y pasa... Sus cuerpos son, desafortunadamente, desechables".

Con Señora de la miel (1996), la más internacionalmente difundida de sus novelas -traducida al italiano, el francés, el holandés, el alemán y el inglés- Buitrago regresa geográfica y temáticamente al Caribe. El título de la novela mismo es un homenaje a sus 
raíces intelectuales caribeñas, a "las estrellas de la miel" mencionadas en Respirando el verano de Héctor Rojas Herazo: "Él decía que 'a uno se lo inventan los amigos'... yo pensé en un personaje de Rojas pero inventado por mí, y salió así”. La novela es una suerte de parábola burlesca, fruto de ese doble movimiento que registra Benítez Rojo en Los pañamanes: representar para develar y cancelar un mito preexistente y para plantear las bases de un nuevo mito. El mito por cancelar en este caso es el de la superpotencia del macho caribeño, exacerbada y refutada en la fabulosa historia de Teodora, una costeña cándida, voluptuosa y mágica, dividida entre el deseo por su marido, galán de pueblo y prototipo jocoso del macho caribeño, y su jefe, gurú de la sexualidad que va por el mundo difundiendo el erotismo con bizcochos y esencias.

Señora de la miel exagera algunos de los motivos culturales que han dado lugar al Caribe mítico: desde los poderes sobrenaturales de la protagonista, pitonisa del amor y la sexualidad ajena, pero subyugada por un marido infiel y abusivo, hasta el poder universal del "falo", nombrado y retratado hasta la saciedad como símbolo de las contradicciones tras el supuesto desparpajo sexual caribeño. En esta novela, Buitrago lleva también a su cumbre el efecto satírico de sus textos, acentuado por el lenguaje soez y el humor carnavalesco, con los que emprende una celebración del cuerpo y del erotismo sin precedentes en su novelística. Buitrago insiste, sin embargo, en las bases reales de estos personajes, nutrida de sus repetidas estancias en "los pueblos del mar", a los que dedica también su más reciente volumen de cuentos, Canciones profanas (2009). Tras la historia está, para empezar, un cuento de la tía Mercedes, sobre una joven que heredó a un hombre, "una muchacha a la que la madrina le dice: 'a Fulanito me lo cuida' y Fulanita se pasó toda la vida cuidando al tipo que le ponía los cuernos y trabajando para él". Por eso la novela estaba pensada originalmente como una tragedia, "pero eso en tragedia no funcionaba," comenta la autora. Hasta que "en Grecia un día se me ocurrió: esto hay que contarlo pero es pa' que la gente se ría. i¿Qué tal que a mí me dejen de herencia un tipo y yo me dedique a cuidarlo?!". En la génesis de los personajes están la esposa de un amigo que les hablaba a las plantas y así las revivía; "una Norca, de ésas que van por la vida de gordas, como que todo el mundo las quiere, pero que el marido le ponía los cuernos hasta con el gato y ella ni se enteraba" y un vecino de la infancia, el "niño más lindo del pueblo," al que descubriría décadas más tarde borracho con una de sus amantes sobre un burro, convertido en "un tipo gordo que se le salía la panza, una panza gelatinosa y blanca; descalzo y con un sombrero carísimo y lentes ahumados".

En esa vuelta imaginaria al Caribe, desde una parodia algo nostálgica a la vida "a flor de piel" que resuman sus personajes, Buitrago sitúa la parábola de una forma de amor y de sensualidad otra, libre, desde la agencia sexual que Teodora encuentra al final de la novela. Teodora conjura así la tragedia implícita en el mito patriarcal original que determina el destino de las protagonistas de El hostigante, cuyas narradoras sucumben

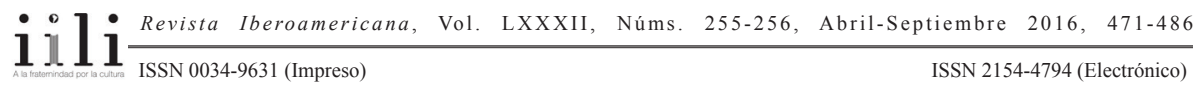


ante la seducción de "los dioses". Señora de la miel es un punto de llegada, y de reinicio, en la trayectoria literaria y vital de una escritora única e inimitable.

Reposan en sus cajones un sin fin de sorpresas, entre ellas dos novelas terminadas, tan diversas entre sí como todo lo que ha publicado. Al hacer el balance, Buitrago dice que le preocupa que no le alcance el tiempo para escribir todo lo que aún tiene para contar. Por lo demás,

pienso que me ha tocado gente maravillosa, que he conocido unos personajes y personas fuera de serie, y que he amado muchísimo. Que me han querido muchísimo. Que he tenido unos amigos estupendos... escritores... escritoras... y alrededor he conocido pintores, actores, ceramistas, publicistas, modelos, vendedores de cigarrillos. Vendedores de zapatos. Vagos, drogadictos también, porque para que nos vamos a decir que no. Cajeros de banco, señoras bien, señores bien...

He tenido una vida muy bella. Y agradezco mucho haberla tenido.

\section{BiBLIOGRAFÍA}

Arbeláez, Fernando. Nuevos narradores colombianos. Caracas: Monte Ávila Editores, 1968.

Aristizábal, Patricia. Panorama de la narrativa femenina en Colombia en el Siglo XX. Cali: Universidad del Valle, 2005.

Benítez Rojo, Antonio. La Isla que se repite: El Caribe y la perspectiva posmoderna. Hanover: Ediciones del Norte, 1989.

Borsó, Victoria. "La escritura femenina en Colombia en la década de los 80”. La novela colombiana ante la crítica. 1975-1990. Luz Mary Giraldo, ed. Bogotá y Cali: Centro Editorial Javeriano, 1994. 71-96.

Buitrago, Fanny. "Un cielo blanco, de nubes blancas”. El Espectador. 10 junio 1962. Magazín Dominical sec.

“Un helado de moras para Juanita Campana". El Tiempo. 3 dic. 1961, Lecturas Dominicales sec.

“Hoy es mi cumpleaños”. El Espectador. 25 junio 1961. Magazín Dominical sec. “El niño, el búho y la lluvia”. El Tiempo. 28 mayo 1961. Lecturas Dominicales sec. "El oficio no oficio de escribir". Revista de Estudios Colombianos 9 (1990): 3-6. “El verso aquel, el sexo aquel". Quimera 9 (1991): 25-28.

Entrevista personal. 2007.

Entrevista personal. 2008.

Entrevista personal. 2010.

Buitrago, Letty. Correspondencia a la autora. 2007-2011.

Calderón, Camilo. "El nuevo libro de Fanny Buitrago. 'Los amores de Afrodita' 5 novelas cortas basadas en historias reales”. Al día 118 (1983): 41-45. 
Gilard, Jacques. Prólogo. Algo tan feo en la vida de una señora bien. Marvel Moreno. Bogotá: Editorial Pluma, 1980. i-vii.

Giraldo, Luz Mery. "Fanny Buitrago de relatos y retratos". La novela colombiana ante la crítica. 1975-1990. Luz Mary Giraldo, ed. Bogotá: Editorial Facultad de Humanidades y Centro Editorial Javeriano, 1994. 203-216.

Martínez, Alejandro. "El hostigante verano de los dioses". Magazín Dominical. El Espectador. 17 marzo 1985.

Menton, Seymour. Caminata por la narrativa latinoamericana. México D.F.: Fondo de cultura económica, 2002.

"La novelística de la costa colombiana: especulaciones históricas". AIH. Actas IX (1986): 629-34. 12 marzo 2012. <http://cvc.cervantes.es/literatura/aih/pdf/09/ aih_09_2_072.pdf\%3E $>$. 11 julio 2015 .

Montes Garcés, Elizabeth. El cuestionamiento de los mecanismos de representación en la novelística de Fanny Buitrago. Nueva York: Peter Lang, 1997.

"El cuestionamiento de la autoridad de los mecanismos de representación en la novelística de Fanny Buitrago". Literatura y diferencia: Escritoras colombianas del siglo XX. María Mercedes Jaramillo, Betty Osorio de Negret y Ángela Inés Robledo, eds. Bogotá, Medellín: Uniandes; Ed. Univ. de Antioquia, 1995.

Ordóñez Muñoz, Jorge Eliécer. "Estructura mítica en 'El hostigante verano de los dioses". Cuadernos de Literatura del Caribe e Hispanoamérica 2 (2005): 24-42.

Ortega, Manuel Guillermo et al. La obra de Fanny Buitrago. Crítica. Número especial de Cuadernos de Literatura del Caribe e Hispanoamérica 2 (2005).

Peña Gutiérrez, Isaías. "La generación del bloqueo y del estado de sitio". Bogotá: Ediciones Punto Rojo, 1973.

Rodríguez Garavito, Agustín. "Reseña de El hostigante verano de los dioses de Fanny Buitrago". Boletín Cultural y Bibliográfico 6/6 (1963): 838-39.

Santos Febres, Mayra. Sobre piel y papel. San Juan: Ediciones Callejón, 2005.

Trujillo Mejía, Laura.“Advertencias, prólogos y noticias: Desplazamiento de lo liminal en la obra de Fanny Buitrago". Literatura y cultura: Narrativa colombiana del siglo XX, II: Diseminación, cambios, desplazamientos. María Mercedes Jaramillo, Betty Osorio y Ángela I. Robledo, eds. Bogotá: Ministerio de Cultura, 2000. 71-97.

Williams, Raymond L. Una década de novela colombiana: La experiencia de los setenta. Bogotá: Plaza y Janés, 1981.

"An Interview with Women Writers in Colombia." Latin American Women Writers: Yesterday and Today. Yvette E. Miller y Charles M. Tatum, eds. Pittsburgh, PA: Latin American Literary Review, 1977. 155-161. 